\section{OPEN ACCESS}

Edited and Reviewed by:

Mariagrazia Uguccioni,

Institute for Research in Biomedicine,

Switzerland

*Correspondence

Mette M. Rosenkilde

rosenkilde@sund.ku.dk

Specialty section: This article was submitted to Cytokines and Soluble Mediators in Immunity,

a section of the journal Frontiers in Immunology

Received: 13 January 2017 Accepted: 19 January 2017 Published: 08 February 2017

Citation:

Hjortø GM, Larsen O, Steen A, Daugvilaite V, Berg C, Fares S, Hansen M, Ali S and Rosenkilde MM (2017) Corrigendum: Differential

CCR7 Targeting in Dendritic Cells

by Three Naturally Occurring CC-Chemokines.

Front. Immunol. 8:89.

doi: 10.3389/fimmu.2017.00089

\title{
Corrigendum: Differential CCR7 Targeting in Dendritic Cells by Three Naturally Occurring CC-Chemokines
}

\author{
Gertrud M. Hjortø', Olav Larsen', Anne Steen', Viktorija Daugvilaite1, Christian Berg', \\ Suzan Fares ${ }^{1}$, Morten Hansen ${ }^{2}$, Simi Ali ${ }^{3}$ and Mette M. Rosenkilde ${ }^{1 *}$ \\ ${ }^{1}$ Faculty of Health and Medical Sciences, Department of Neuroscience and Pharmacology, The Panum Institute, University \\ of Copenhagen, Copenhagen, Denmark, ' ${ }^{2}$ Department of Haematology, Center for Cancer Immune Therapy (CCIT), \\ Copenhagen University Hospital, Herlev, Denmark, ${ }^{3}$ Medical Faculty, Institute of Cellular Medicine, Newcastle University, \\ Newcastle upon Tyne, UK
}

Keywords: CCR7, CCL19, CCL21, tailless-CCL21, dendritic cell, biased signaling, ERK

\section{A corrigendum on}

Differential CCR7 Targeting in Dendritic Cells by Three Naturally Occurring CC-Chemokines by Hjortø GM, Larsen O, Steen A, Daugvilaite V, Berg C, Fares S, et al. Front Immunol (2016) 7:568. doi:10.3389/fimmu.2016.00568

\section{Funding}

This study was supported by the Danish Council for Independent Research, Medical Sciences, the Novo Nordisk Foundation, the Lundbeck Foundation, the A. P. Møller Foundation for the Advancement of Medical Science, the Aase and Einar Danielsen Foundation, the Hørslev Foundation, the Gangsted Foundation, Scleroseforeningen, Fonden for Neurologisk forskning, grant FP7-MC-ITN (POSAT, 606979), and the Carlsberg Foundation grant number 2013_01_0694 and CF14-0690.

\section{Clarification of Corrigendum:}

In the original article, we neglected to acknowledge the Carlsberg Foundation, grant number 2013_01_0694 and CF14-0690 to MR. The authors apologize for this oversight.

This error does not change the scientific conclusions of the article in any way.

Conflict of Interest Statement: The authors declare that the research was conducted in the absence of any commercial or financial relationships that could be construed as a potential conflict of interest.

Copyright (®) 2017 Hjortø, Larsen, Steen, Daugvilaite, Berg, Fares, Hansen, Ali and Rosenkilde. This is an open-access article distributed under the terms of the Creative Commons Attribution License (CC BY). The use, distribution or reproduction in other forums is permitted, provided the original author(s) or licensor are credited and that the original publication in this journal is cited, in accordance with accepted academic practice. No use, distribution or reproduction is permitted which does not comply with these terms. 